\title{
Literasi Karbon dalam kalangan Pelajar Sekolah Menengah Rendah: Kajian Kes di Wilayah Persekutuan Putrajaya
}

\author{
Saiyidatina Balkhis Norkhaidi*, Hanifah Mahat, Mohmadisa Hashim, Nasir Nayan, Yazid Saleh
}

Jabatan Geografi dan Alam Sekitar, Fakulti Sains Kemanusiaan, Universiti Pendidikan Sultan Idris, 35900 Tanjong Malim, Perak, Malaysia

*Corresponding author: m20151000194@siswa.upsi.edu.my

\begin{abstract}
Carbon literacy is a key medium to enhance the understanding of an individual's consciousness on reducing carbon emissions in the atmosphere towards addressing the issue of global warming and climate change. This article aims to identify the level of carbon literacy among lower secondary schools students in Malaysia. The study involved 463 Form 2 students from eleven schools in the Federal Territory of Putrajaya. The schools were selected using a systematic sampling and respondents were selected using a simple random sampling. Questionnaire Likert scale of 1 to 5 were used as a research instrument. Carbon literacy variable studies include four variables, namely the carbon footprint knowledge, low carbon attitudes, carbon literate value and low carbon practices. Carbon footprint knowledge variables consist of six sub variables: energy saving, recycling, mode of travel, carbon footprint, air pollution and the greenhouse effect. As for the variables of carbon literacy attitude, sub variables consist of energy saving, recycling and mode of travel followed by sub variables of carbon literacy value of the individual and the society. And for the practice of low-carbon, it consists of sub variables, namely energy saving, recycling and mode of travel. Result showed that the questionnaire reliability obtained with Cronbach alpha values for each variable was greater than 0.7. Meanwhile, the level of knowledge of the carbon footprint, low-carbon attitudes, values and practices of low-carbon literacy carbon is at a high level as a whole except for the variable sub knowledge that air pollution is moderate. These findings demonstrated that carbon literacy level of students at the high level and the situation are clear implications of a positive target inapplicable in Federal Territory of Putrajaya towards a Low Carbon City and Green City in 2025.
\end{abstract}

Keywords: Carbon literacy, carbon footprint knowledge, low carbon attitude, carbon literacy value, low carbon practices

\begin{abstract}
Abstrak
Literasi karbon merupakan medium utama dalam mempertingkatkan kefahaman individu mengenai kesedaran dalam memiminumkan pelepasan karbon di atmosfera bagi menangani isu pemanasan global dan perubahan iklim dunia. Artikel ini bertujuan untuk mengenal pasti tahap literasi karbon dalam kalangan pelajar sekolah menengah rendah di Malaysia. Kajian melibatkan 463 orang pelajar Tingkatan 2 daripada sebelas buah sekolah menengah di Wilayah Persekutuan Putrajaya. Pemilihan sekolah adalah dengan menggunakan kaedah pensampelan sistematik manakala pemilihan responden adalah dengan menggunakan kaedah pensampelan rawak mudah. Instrumen soal selidik berskala Likert 1 hingga 5 digunakan sebagai instrumen kajian. Pemboleh ubah literasi karbon yang dikaji meliputi empat pemboleh ubah iaitu pengetahuan jejak karbon, sikap rendah karbon, nilai celik karbon dan amalan rendah karbon. Pemboleh ubah pengetahuan jejak karbon terdiri daripada enam sub pemboleh ubah iaitu penjimatan tenaga, aktiviti kitar semula, mod perjalanan, jejak karbon, pencemaran udara dan kesan rumah hijau. Manakala bagi pemboleh ubah sikap celik karbon, sub pemboleh ubah terdiri daripada penjimatan tenaga, aktiviti kitar semula dan mod perjalanan. Diikuti dengan sub pemboleh ubah nilai celik karbon iaitu nilai individu dan nilai masyarakat. Seterusnya bagi amalan rendah karbon, sub pemboleh ubah terdiri daripada sub pemboleh ubah iaitu penjimatan tenaga, aktiviti kitar semula dan mod perjalanan. Hasil kajian menunjukkan tahap kebolehpercayaan soal selidik boleh diterima dengan nilai alfa Cronbach bagi setiap pemboleh ubah adalah lebih besar daripada 0.7. Manakala bagi tahap pengetahuan jejak karbon, sikap rendah karbon, nilai celik karbon dan amalan rendah karbon dapatan kajian menunjukkan tahap keempat-empat pemboleh ubah berada pada tahap yang tinggi secara keseluruhannya kecuali sub pemboleh ubah pengetahuan pencemaran udara yang berada pada tahap sederhana. Dapatan ini membuktikan tahap literasi karbon pelajar berada pada tahap tinggi dan dapatan ini jelas memberi implikasi positif ke arah Wilayah Persekutuan Putrajaya sebagai Bandar Rendah Karbon dan Bandar Hijau 2025.
\end{abstract}

Kata kunci: Literasi karbon, pengetahuan jejak karbon, sikap rendah karbon, nilai celik karbon, amalan rendah karbon

(C) 2017 Penerbit UTM Press. All rights reserved

\subsection{PENGENALAN}

Aktiviti manusia pada masa kini secara tidak langsung telah menyumbang kepada pemanasan global dan perubahan iklim dunia. Sumbangan terbesarnya berasal dari pembakaran bahan api fosil, yang membebaskan gas karbon dioksida ke atmosfera (Riebeek, 2007). Sejak bermulanya era perindustrian, kesan keseluruhan aktiviti manusia ke atas iklim telah membawa kesan pemanasan global. Menerusi laporan Intergovernmental Panel on Climate Change (IPCC), dapatan membuktikan bahawa suhu permukaan global akan meningkat daripada 1.1 kepada 6.4 darjah celsius pada abad ke-21 selepas bumi semakin panas pada tahun 1990 (Intergovernmental Panel on Climate Change (IPCC), 2014). 
Perubahan iklim ini akan menguatkan risiko sedia ada dan mewujudkan risiko baru untuk sistem semula jadi dan kehidupan manusia (Intergovernmental Panel on Climate Change (IPCC), 2014). Dalam konteks kehidupan manusia, fenomena ini dilihat telah menjejaskan kesihatan dan ketidakselesaan manusia. Pelbagai penyakit seperti kerosakan kanta mata, kanser kulit, malahan berlaku mutasi dalam sistem kromosom manusia berlaku akibat implikasi daripada kejadian ini (World Health Organization, 2016). Hal ini dapat dilihat dengan lebih jelas apabila manusia menghadapi sindrom down dan sindrom turner akibat daripada mutasi kromosom (Gioconda, Denisse, \& Alfredo, 2016).

Lantaran itu dalam usaha dalam mengurangkan impak negatif ini kepada alam sekitar dan aktiviti harian manusia, tanggungjawab ini haruslah digalas oleh setiap individu, komuniti, negara dan global. Antara usaha yang dapat dilihat dalam mengurangkan impak pemanasan global dalam konteks pelepasan karbon adalah dengan wujudnya Protokol Montreal (1989) yang merupakan salah satu daripada Perjanjian Alam Sekitar Pelbagai Hala (MEAs) yang bertujuan menyelesaikan masalah atmosfera global. Begitu juga Protokol Kyoto (1997) yang merupakan persetujuan dalam Persidangan Rangka Kerja PBB tentang Perubahan Iklim (UNFCCC), yang diterima sejagat tentang perihal pemanasan global (Muhammad Rizal \& Jamaluddin, 2010). Negara-negara yang terlibat bersetuju untuk melaksanakan protokol ini di negara masing-masing dan berkomitmen untuk mengurangkan pembebasan gas karbon dioksida dan lima gas rumah kaca lain, atau bekerjasama dalam perdagangan kontrak pembebasan gas jika mereka menjaga jumlah atau menambah pembebasan gas-gas tersebut, yang menjadi punca gejala pemanasan global.

Komitmen dan usaha negara Malaysia untuk menjadi negara maju yang lestari telah direncanakan dalam Rancangan Malaysia Kesebelas (RMK11), perancangan Malaysia Pasca 2020 berteraskan daripada pengetahuan dan amalan menjaga alam sekitar. Fokus kerajaan Malaysia adalah bagi membuat perubahan negara daripada trajektori pembangunan konvensional 'Grow First - Pembangunan Didahulukan, 'Clean Up Later' - Pembersihan Kemudian yang berkos tinggi kepada trajektori pertumbuhan hijau yang akan memastikan pembangunan sosio ekonomi dilaksanakan secara mapan bermula pada peringkat perancangan dan seterusnya pada peringkat pelaksanaan dan penilaian dan bagi membendung masalah pemanasan global ini (Unit Perancang Ekonomi, 2015). Selain itu penerapan melalui agen pendidikan dalam menjaga alam sekitar telah dilaksanakan sejak awal lagi dan peranan pendidikan dalam alam sekitar telah banyak diutarakan dan diketengahkan dalam persidangan sama ada di peringkat nasional mahupun antarabangsa (Hanifah, Shaharudin, Mohmadisa, Nasir, \& Yazid, 2015). Maka dengan itu, suatu kajian perlu dilaksanakan bagi mengkaji keberkesanan pendidikan sedia dalam konteks pengetahuan, sikap, nilai dan amalan pelajar dalam usaha mencapai fokus kerajaan ini. Oleh itu, artikel ini adalah bertujuan bagi mengkaji tahap literasi karbon pelajar sekolah menengah yang dipecahkan kepada empat pemboleh ubah iaitu pengetahuan jejak karbon, sikap rendah karbon, nilai celik karbon dan amalan rendah karbon.

\subsection{KESEDARAN LITERASI KARBON DI MALAYSIA}

Masyarakat di Malaysia sudah mula memperlihatkan perubahan besar dalam soal kelestarian alam sekitar berikutan perkembangan kemudahan komunikasi tanpa sempadan bagi mendapatkan maklumat berkaitan alam sekitar (Rosnani, 2011). Perkembangan dunia tanpa sempadan secara tidak langsung dapat meningkatkan tahap literasi masyarakat di Malaysia. Literasi secara amnya merupakan keupayaan mengenal pasti, memahami, mentafsir, mencipta, menyampaikan, mengira dan menggunakan bahan cetak dan bertulis yang berkenan dengan pelbagai konteks (UNESCO, 2006). Dalam konteks yang lebih tepat, literasi bermaksud mampu membaca dan menulis pada tahap yang memadai untuk berkomunikasi atau tahap yang membolehkan seseorang memahami dan meluahkan pandangan dalam masyarakat celik huruf agar dapat bergaul dalam kalangan masyarakat (Cambridge Assessment, 2013).

Literasi dan alam sekitar saling berkaitan antara satu sama lain dalam memberikan pengetahuan, kemahiran intelektual, sikap, pengalaman dan motivasi kepada individu dan komuniti dalam bertindak balas terhadap alam sekitar (Maryland Association for Environmental \& Outdoor Education (MAEOE), 2016). Kajian mengenai literasi yang melibatkan alam sekitar dapat dilihat melalui kajian pengkaji yang lalu seperti kajian literasi alam sekitar, literasi iklim, literasi ekologi dan literasi tenaga. Literasi alam sekitar didefinisikan sebagai suatu panduan multidimensi yang merangkumi dimensi kognitif (pengetahuan dan kemahiran), afektif dan tanggungjawab tingkah laku alam sekitar. Individu atau kumpulan terlibat dalam mempamerkan tingkah laku pro alam sekitar (Joseph, Nichol, Janggu, \& Madi, 2013). Menurut kajian Salwati (2013) literasi alam sekitar merangkumi empat konstruk iaitu pengetahuan, kemahiran, afektif dan tingkah laku dan sebelas lagi komponen iaitu ekologi, sains alam sekitar, kepekaan, sikap, kawalan lokus, tanggungjawab individu, kesanggupan terlibat, pengurusan eko, tindakan memujuk, tindakan pengguna dan tindakan undang-undang diperoleh. Namun begitu, jika salah satu konteks ini tidak mencapai kriteria yang dikehendaki, literasi alam sekitar yang terhasil tidak akan seimbang.

Seterusnya literasi iklim pula adalah pemahaman pengaruh individu kepada iklim dan pengaruh iklim ke atas individu dan masyarakat (United States Global Change Research Program, 2009). Individu yang celik iklim memahami prinsip-prinsip penting sistem iklim bumi, tahu untuk mencari maklumat berkenaan dengan iklim, membincangkan isu dan perubahan iklim dan berupaya untuk membuat keputusan yang bertanggungjawab dan membuat tindakan yang memberi kesan positif kepada iklim. Literasi ekologi atau eko-literasi pula adalah literasi yang mengukur pengetahuan seseorang dalam sistem ekologi, menjaga persekitaran dan global serta tahap tindakan mereka untuk mengurangkan kesan tindakan individu dan orang ramai terhadap alam sekitar (Anna, 2014). Terdapat tiga komponen iaitu pengetahuan, akibat dan tingkah laku yang perlu digabungkan untuk membentuk individu yang celik ekologi (Bruyere, 2008; Orr, 1992). Manakala literasi tenaga (energy literacy) pula bermaksud kefahaman dalam memahami alam sekitar dan fungsi tenaga kepada dunia dan kehidupan manusia (Chikaire, Ani, Nnadi, \& Godson-Ibeji, 2015). Individu yang mempunyai pengetahuan literasi tenaga adalah individu yang celik tenaga (energy literate). Individu ini mempunyai pemahaman asas tentang konsep tenaga (Barrow \& Morrisey, 1989). Menurut DeWaters dan Powers (2012) terdapat tiga dimensi dalam literasi tenaga iaitu kognitif (pengetahuan), afektif (sikap, nilai) dan tingkahlaku. Jika dilihat keempat-empat kajian literasi ini, ianya saling berkaitan antara satu sama lain dan secara tidak langsung mempunyai hubungan dengan literasi karbon. Tanpa kewujudan literasi alam sekitar, literasi iklim, literasi ekologi dan literasi tenaga, kesedaran mengenai literasi karbon juga tidak akan wujud.

Literasi karbon adalah merupakan amalan sosial yang berkaitan dengan pengetahuan kitar karbon (Candice, 2013). Literasi karbon didefinisikan sebagai kesedaran mengenai kos karbon dioksida dan impak daripada aktiviti harian manusia serta keupayaan dan motivasi individu, masyarakat dan organisasi dalam mengurangkan pelepasan karbon (Manchester Carbon Literacy Project, 2012). Elemen literasi karbon terdiri daripada pengetahuan, nilai dan sikap yang akan membentuk tingkah laku rendah karbon (Nor Juliana, Mohd Yazid, 
Nor Atiah, \& Md Azree, 2015). Secara ringkasnya, literasi karbon adalah merupakan amalan celik kepada isu karbon dari segi kitaran dan amalan kelestarian rendah karbon.Kompenen kesedaran literasi karbon adalah berdasarkan Model knowledge, attitude, practice (KAP) yang menekan kewujudan kesedaran berdasarkan tiga elemen iaitu pengetahuan-knowledge, sikap-attitude dan amalan-practice (Schwartz, 1976). Melalui asas kepada model ini, Launiala (2009) membuktikan bahawa pengetahuan, sikap dan amalan masyarakat berfungsi sebagai pendidikan diagnosis masyarakat dalam mengkaji kesedaran kesihatan masyarakat.

Dalam konteks kajian ini, komponen kesedaran literasi karbon diambil kira daripada empat elemen iaitu pengetahuan jejak karbon, sikap rendah karbon, nilai celik karbon dan amalan rendah karbon. Keempat-empat elemen ini dilihat mampu menilai tahap kesedaran literasi pelajar yang diperincikan pada metod kajian ini.

\subsection{METOD KAJIAN}

Kajian ini merupakan kajian tinjauan dengan menggunakan kaedah soal selidik. Pemilihan kaedah ini adalah kerana melibatkan responden yang ramai, lebih luas dan menyeluruh (Ary, Jacob, \& Razaviech, 2002). Dalam konteks kajian ini, tinjauan soal selidik dipilih untuk memperoleh data-data mengenai pengetahuan literasi karbon, sikap rendah karbon, nilai celik karbon dan amalan rendah karbon.

\section{Populasi Dan Sampel Kajian}

Populasi kajian ini adalah melibatkan pelajar sekolah menengah di Wilayah Persekutuan Putrajaya. Sebanyak sebelas buah sekolah menengah di Wilayah Persekutuan Putrajaya telah terlibat dalam kajian ini. Manakala bagi sampel kajian seramai 463 orang pelajar tingkatan 2 diambil menerusi kaedah pensampelan rawak mudah.

\section{Instrumen Kajian}

Soal selidik telah digunakan sebagai instrumen dalam kajian ini. Item soal selidik telah dipecahkan kepada tujuh bahagian iaitu bahagian demografi responden, latar belakang pendidikan alam sekitar responden, latar belakang pengetahuan literasi karbon, pengetahuan literasi karbon, sikap rendah karbon, nilai celik karbon dan amalan rendah karbon. Maklumat kandungan bagi setiap pemboleh ubah dan skala pengukuran setiap pemboleh ubah kajian ini dijelaskan seperti di Jadual 1. Skala pengukuran item bagi setiap pemboleh ubah adalah dengan menggunakan skala Likert 5 mata iaitu untuk penmbolehubah pengetahuan literasi karbon, sikap rendah karbon dan nilai celik karbon, 1=Sangat tidak setuju, 2-Tidak setuju, 3-Kurang setuju, 4-Setuju dan 5-Sangat Setuju. Manakala bagi pemboleh ubah amalan rendah karbon skala likert yang digunakan adalah 1=Tidak Pernah, 2-Kadang-kadang, 3-Sekali-sekala, 4-Selalu dan 5-Sangat Selalu.

Jadual 1 Instrumen kajian

\begin{tabular}{|c|c|c|c|}
\hline Bhg & Huraian & Pemboleh ubah & Sumber Item \\
\hline A & Latar Belakang Responden & $\begin{array}{l}\text { Jantina } \\
\text { Kaum } \\
\text { Kehadiran program menjaga } \\
\text { alam sekitar }\end{array}$ & Dibina sendiri mengikut keperluan kajian \\
\hline B & $\begin{array}{l}\text { Latar Belakang Pendidikan } \\
\text { Alam Sekitar Responden }\end{array}$ & $\begin{array}{l}\text { Penganjur program menjaga } \\
\text { alam sekitar } \\
\text { Peringkat program menjaga } \\
\text { alam sekitar } \\
\text { Jenis program menjaga alam } \\
\text { sekitar }\end{array}$ & $\begin{array}{l}\text { Dibina dengan ubahsuai dan merujuk kepada kajian dan } \\
\text { merujuk kepada } \\
\text { Hanifah (2014) }\end{array}$ \\
\hline $\mathrm{C}$ & $\begin{array}{l}\text { Latar Belakang Pengetahuan } \\
\text { Literasi Karbon }\end{array}$ & $\begin{array}{l}\text { Istilah-istilah dalam literasi } \\
\text { karbon } \\
\text { Sumber informasi kesedaran } \\
\text { literasi karbon }\end{array}$ & Dibina sendiri mengikut keperluan kajian \\
\hline & Pengetahuan Literasi Karbon & & \\
\hline & Penjimatan Tenaga & & \\
\hline $\mathrm{D}$ & $\begin{array}{l}\text { Aktiviti Kitar Semula } \\
\text { Mod Perjalanan } \\
\text { Jejak Karbon } \\
\text { Pencemaran Udara } \\
\text { Kesan Rumah Hijau } \\
\text { Sikap Rendah Karbon }\end{array}$ & & $\begin{array}{l}\text { Dibina dengan ubahsuai dan merujuk kepada KeTTHA } \\
\text { (2015), }\end{array}$ \\
\hline $\mathrm{E}$ & $\begin{array}{l}\text { Penjimatan Tenaga } \\
\text { Aktiviti Kitar Semula } \\
\text { Mod Perjalanan }\end{array}$ & & $\begin{array}{l}\text { Dibina dengan ubahsuai dan merujuk kepada Hussain, } \\
\text { Ismail dan Noh (2013), Persatuan Penyelidikan Air dan } \\
\text { Tenaga Malaysia (2012) dan KeTTHA (2015) }\end{array}$ \\
\hline $\mathrm{F}$ & $\begin{array}{l}\text { Nilai Celik Karbon } \\
\text { Individu } \\
\text { Masyarakat } \\
\text { Amalan Rendah Karbon }\end{array}$ & & $\begin{array}{l}\text { Dibina dengan ubahsuai dan merujuk kepada Shahrom et } \\
\text { al. (2009) }\end{array}$ \\
\hline G & $\begin{array}{l}\text { Penjimatan Tenaga } \\
\text { Aktiviti Kitar Semula } \\
\text { Mod Perjalanan }\end{array}$ & & $\begin{array}{l}\text { Dibina dengan ubahsuai dan merujuk kepada KeTTHA } \\
\text { (2015) }\end{array}$ \\
\hline $\mathrm{H}$ & Soalan Terbuka & Pandangan/cadangan & \\
\hline
\end{tabular}


Jadual 2 juga menunjukkan keempat-empat pemboleh ubah menunjukkan nilai kebolehpercayaan Alpha Cronbach melebihi 0.7 iaitu pada aras yang boleh diterima (Lance, Butts \& Michels, 2006). Instrumen kajian juga telah melalui semakan kesahan pakar kandungan oleh lima orang ahli akademik Universiti Pendidikan Sultan Idris dan Universiti Kebangsaan Malaysia. Bagi kesahan muka, lima orang pelajar Tingkatan 3 turut terlibat bagi menguji kesesuaian dan kefahaman kandungan soal selidik.

Jadual 2 Nilai kebolehpercayaan item kajian

\begin{tabular}{clcc}
\hline Bahagian & \multicolumn{1}{c}{ Pemboleh ubah } & Bil Item & $\begin{array}{c}\text { Nilai Alpha Cronbach } \\
\text { (Murid) }\end{array}$ \\
\hline D & Pengetahuan Literasi Karbon & 30 & 0.863 \\
E & Sikap Celik Karbon & 18 & 0.861 \\
F & Nilai Celik Karbon & 18 & 0.930 \\
G & Amalan Literasi Karbon & 18 & 0.879 \\
\hline
\end{tabular}

\subsection{DAPATAN DAN PERBINCANGAN KAJIAN}

\section{Latar Belakang Responden}

Perbincangan dapatan kajian dibahagikan kepada dua bahagian iaitu latar belakang responden dan tahap kesedaran literasi karbon responden. Bagi latar belakang responden, dapatan kajian turut membincangkan mengenai latar belakang pendidikan alam sekitar responden dan latar belakang pengetahuan literasi karbon responden. Bagi tahap kesedaran literasi karbon responden, dapatan kajian dibahagikan mengikut pemboleh ubah kajian iaitu pengetahuan literasi karbon, sikap rendah karbon, nilai celik karbon dan amalan rendah karbon.

Jadual 3 menunjukkan latar belakang responden yang terdiri daripada 463 orang pelajar Tingkatan 2 sekolah menengah di Wilayah Persekutuan Putrajaya iaitu seramai 228 orang (49.2\%) pelajar lelaki dan 235 orang (50.8\%) pelajar perempuan. Majoriti kaum responden yang terlibat dalam kajian ini adalah Melayu iaitu seramai 454 orang (98.1\%), diikuti dengan Bumiputera Sarawak seramai 4 orang $(0.9 \%)$, India dan Bumiputera Sabah masing-masing seramai 2 orang $(0.4 \%)$ dan seorang kaum Cina $(0.2 \%)$.

Jadual 3 Latar belakang responden

\begin{tabular}{llcc}
\hline & Latar Belakang Responden & $\mathbf{N}$ & $\mathbf{\%}$ \\
\hline Jantina & Lelaki & 228 & 49.2 \\
& Perempuan & 235 & 50.8 \\
& Jumlah & $\mathbf{4 6 3}$ & $\mathbf{1 0 0}$ \\
& & \\
Kaum & & 98.1 \\
& Melayu & 454 & 0.2 \\
& Cina & 1 & 0.4 \\
India & 2 & 0.4 \\
Bumiputera Sabah & 2 & 0.9 \\
Bumiputera Sarawak & 4 & $\mathbf{1 0 0}$ \\
\hline
\end{tabular}

Bagi latar belakang pengetahuan literasi karbon responden, Jadual 4 menunjukkan 175 orang (37.8\%) responden mendapat informasi mengenai kesedaran menjaga alam sekitar bagi mengurangkan kesan rumah hijau melalui buku ilmiah, 182 orang (39.2\%) melalui majalah, 193 orang $(41.7 \%)$ laman web, 303 orang $(65.4 \%)$ rancangan televisyen dan 261 orang (56.4\%) melalui ceramah dan pameran. 
Jadual 4 Latar belakang pengetahuan literasi karbon responden

\begin{tabular}{|c|c|c|c|}
\hline \multicolumn{2}{|c|}{ Latar Belakang Pengetahuan Literasi Karbon Responden } & $\mathbf{N}$ & $\%$ \\
\hline \multicolumn{4}{|c|}{$\begin{array}{l}\text { Di manakah anda mendapat informasi mengenai kesedaran menjaga alam sekitar bagi mengurangkan kesan rumah } \\
\text { hijau? }\end{array}$} \\
\hline \multirow{3}{*}{ Buku ilmiah } & Ya & 175 & 37.8 \\
\hline & Tidak & 288 & 62.2 \\
\hline & Jumlah & 463 & 100 \\
\hline \multirow[t]{3}{*}{ Majalah } & Ya & 182 & 39.3 \\
\hline & Tidak & 281 & 60.7 \\
\hline & Jumlah & 463 & 100 \\
\hline \multirow[t]{3}{*}{ Laman web } & Ya & 193 & 41.7 \\
\hline & Tidak & 270 & 58.3 \\
\hline & Jumlah & 463 & 100 \\
\hline \multirow[t]{3}{*}{ Rancangan televisyen } & Ya & 303 & 65.4 \\
\hline & Tidak & 160 & 34.6 \\
\hline & Jumlah & 463 & 100 \\
\hline \multirow[t]{3}{*}{ Ceramah dan pameran } & Ya & 261 & 56.4 \\
\hline & Tidak & 202 & 43.6 \\
\hline & Jumlah & 463 & 100 \\
\hline
\end{tabular}

Tahap Kesedaran Literasi Karbon Responden

Kajian ini melibatkan empat pemboleh ubah utama iaitu pemboleh ubah pengetahuan literasi karbon, sikap rendah karbon, nilai celik karbon dan amalan rendah karbon. Bagi pengetahuan literasi karbon terdapat enam sub pemboleh ubah iaitu penjimatan tenaga, aktiviti kitar semula, mod perjalanan, jejak karbon, pencemaran udara dan kesan rumah hijau. Manakala bagi pemboleh ubah sikap celik karbon, sub pemboleh ubah terdiri daripada penjimatan tenaga, aktiviti kitar semula dan mod perjalanan. Seterusnya bagi nilai celik karbon, sub pemboleh ubahnya terdiri dua sub pemboleh ubah iaitu nilai individu dan nilai masyarakat. Dan pemboleh ubah terakhir iaitu amala rendah karbon, sub pemboleh ubah terdiri daripada sub pemboleh ubah yang sama dengan sikap rendah karbon iaitu penjimatan tenaga, aktiviti kitar semula dan mod perjalanan.

Analisis tahap pengetahuan dan kemahiran akan melibatkan analisis secara deskriptif iaitu min, peratus, sisihan piawai dan tahap secara keseluruhan. Tahap dalam kajian ini adalah berdasarkan nilai petunjuk nilai maksimum min iaitu lima yang kemudian di bahagikan kepada tiga bahagian iaitu tahap rendah (skor 1.00-2.33), tahap sederhana (skor 2.34-3.66) dan tahap tinggi (skor 3.67-5.00). Analisis tahap pemboleh ubah kajian melibatkan (i) tahap pengetahuan literasi karbon responden, (ii) tahap sikap rendah karbon responden (iii) tahap nilai celik karbon responden dan (iv) tahap amalan rendah karbon responden.

Berdasarkan Jadual 5 memperlihatkan pemboleh ubah tahap pengetahuan literasi karbon responden secara keseluruhan iaitu pada tahap rendah seramai 3 orang $(0.6 \%)$, tahap sederhana seramai 112 orang $(24.2 \%)$ dan tahap tinggi seramai 348 orang (75.2\%). Ini jelas menunjukkan tahap pengetahuan literasi karbon responden secara keseluruhannya adalah pada tahap tinggi $(\mathrm{min}=3.94 \mathrm{dan} \mathrm{SP}=0.47)$. Bagi sub pemboleh ubah tahap pengetahuan literasi karbon responden iaitu penjimatan tenaga, aktiviti kitar semula, mod perjalanan, jejak karbon, pencemaran udara dan kesan rumah hijau, dapatan menunjukkan tahap pengetahuan responden berada pada tahap yang tinggi kecuali sub pemboleh ubah pencemaran udara yang menunjukkan dapatan pada tahap sederhana. Ini menunjukkan tahap pengetahuan literasi karbon pelajar adalah berada pada tahap yang memuaskan. Dapatan ini disokong oleh kajian Puteri Musfirah (2011) yang menunjukkan tahap pengetahuan pelajar sekolah menengah di Serdang ke atas penggunaan lestari dan menjurus kepada amalan rendah karbon adalah pada tahap tinggi. Begitu juga dapatan kajian Norzalika (2011) dalam kalangan pelajar di Taman Medan turut menunjukkan hasil kajian yang sama.

Jadual 5 Tahap pengetahuan literasi karbon

\begin{tabular}{|c|c|c|c|c|c|c|c|c|c|}
\hline \multirow{2}{*}{ Pemboleh ubah } & \multicolumn{2}{|c|}{ Tahap Rendah } & \multicolumn{2}{|c|}{ Tahap Sederhana } & \multicolumn{2}{|c|}{ Tahap Tinggi } & \multirow{2}{*}{ Min } & \multirow{2}{*}{ SP } & \multirow{2}{*}{ Tahap purata } \\
\hline & $\mathbf{N}$ & $\%$ & $\mathbf{N}$ & $\%$ & $\mathbf{N}$ & $\%$ & & & \\
\hline $\begin{array}{l}\text { Pengetahuan Literasi } \\
\text { Karbon }\end{array}$ & 3 & 0.6 & 112 & 24.2 & 348 & 75.2 & 3.94 & 0.47 & Tinggi \\
\hline - Penjimatan Tenaga & 5 & 1.1 & 89 & 19.2 & 369 & 79.7 & 4.17 & 0.61 & Tinggi \\
\hline - Aktiviti Kitar Semula & 4 & 0.9 & 105 & 22.7 & 354 & 76.5 & 3.99 & 0.62 & Tinggi \\
\hline - Mod Perjalanan & 7 & 1.5 & 120 & 25.9 & 336 & 72.6 & 4.07 & 0.70 & Tinggi \\
\hline - Jejak Karbon & 9 & 1.9 & 108 & 23.3 & 346 & 74.7 & 4.09 & 0.74 & Tinggi \\
\hline - Pencemaran Udara & 21 & 4.4 & 203 & 43.8 & 239 & 51.6 & 3.52 & 0.60 & Sederhana \\
\hline - Kesan Rumah Hijau & 14 & 3.0 & 175 & 37.8 & 274 & 59.2 & 3.75 & 0.69 & Tinggi \\
\hline
\end{tabular}

Bagi dapatan tahap sikap rendah karbon responden, sub pemboleh ubah yang dikaji terdiri daripada tiga sub pemboleh ubah iaitu penjimatan tenaga, aktiviti kitar semula dan mod perjalanan. Berdasarkan Jadual 6, dapatan memperlihatkan pemboleh ubah sikap rendah karbon responden secara keseluruhan, sub pemboleh ubah sikap penjimatan tenaga, sub pemboleh ubah aktiviti kitar semula dan sub 
pemboleh ubah mod perjalanan berada pada tahap purata yang tinggi. Ini turut menunjukkan bahawa tahap sikap rendah karbon pelajar berada pada tahap yang baik dan memuaskan seperti mana bagi tahap dalam pengetahuan literasi karbon. Hasil dapatan kajian ini juga adalah selari dengan pendapat Milena, Graham dan Rebecca (2011) yang menyatakan bahawa apabila tahap pengetahuan tinggi, sikap juga turut menunjukkan tahap yang tinggi.

Jadual 6 Tahap sikap rendah karbon

\begin{tabular}{lccccccccc}
\hline \multicolumn{1}{c}{ Pemboleh ubah } & \multicolumn{2}{c}{ Tahap Rendah } & \multicolumn{2}{c}{ Tahap Sederhana } & \multicolumn{2}{c}{ Tahap Tinggi } & \multirow{2}{*}{ Min } & SP & $\begin{array}{c}\text { Tahap } \\
\text { purata }\end{array}$ \\
\hline Tahap Sikap Rendah & $\mathbf{N}$ & $\mathbf{\%}$ & $\mathbf{N}$ & $\mathbf{\%}$ & $\mathbf{N}$ & $\mathbf{\%}$ & & & \\
Karbon & 5 & 1.1 & 141 & 30.5 & 317 & 68.5 & 3.92 & 0.57 & Tinggi \\
- Penjimatan Tenaga & 5 & 1.1 & 175 & 37.8 & 283 & 61.1 & 3.71 & 0.51 & Tinggi \\
- Aktiviti Kitar Semula & 8 & 1.7 & 94 & 20.3 & 361 & 78.0 & 4.13 & 0.71 & Tinggi \\
- Mod Perjalanan & 18 & 3.9 & 136 & 29.4 & 309 & 66.7 & 3.91 & 0.81 & Tinggi \\
\hline
\end{tabular}

Seterusnya, bagi dapatan tahap nilai celik karbon responden, sub pemboleh ubah yang dikaji terdiri daripada dua sub pemboleh ubah iaitu nilai individu dan nilai masyarakat. Jadual 7 menunjukkan tahap nilai celik karbon secara keseluruhan, nilai individu dan nilai masyarakat masing-masing menunjukkan pada tahap yang tinggi. Ini menunjukkan tahap nilai celik karbon pelajar adalah berada pada tahap yang memuaskan dan baik. Dapatan ini juga adalah selari dengan dapatan di bahagian pengetahuan dan sikap yang turut menunjukkan tahap yang sama di mana melalui pengetahuan dan sikap dapat membantu dalam pembentukan nilai seseorang individu dan masyarakat (Tiwi, 2006).

Jadual 7 Tahap nilai celik karbon

\begin{tabular}{lccccccccc}
\hline \multicolumn{1}{r}{ Pemboleh ubah } & \multicolumn{2}{c}{ Tahap Rendah } & \multicolumn{2}{c}{ Tahap Sederhana } & \multicolumn{2}{c}{ Tahap Tinggi } & Min & SP & $\begin{array}{l}\text { Tahap } \\
\text { purata }\end{array}$ \\
& $\mathbf{N}$ & $\mathbf{\%}$ & $\mathbf{N}$ & $\mathbf{\%}$ & $\mathbf{N}$ & $\boldsymbol{\%}$ & & & \\
\hline $\begin{array}{l}\text { Tahap Nilai Celik } \\
\text { Karbon }\end{array}$ & 5 & 1.1 & 101 & 21.8 & 357 & 77.1 & 4.14 & 0.64 & Tinggi \\
- Individu & 7 & 1.5 & 114 & 24.6 & 342 & 73.9 & 4.10 & 0.68 & Tinggi \\
- Masyarakat & 5 & 1.1 & 83 & 17.9 & 375 & 81.0 & 4.19 & 0.69 & Tinggi \\
\hline
\end{tabular}

Manakala bagi dapatan tahap amalan rendah karbon responden, sub pemboleh ubah yang dikaji terdiri daripada tiga sub pemboleh ubah iaitu penjimatan tenaga, aktiviti kitar semula dan mod perjalanan. Berdasarkan Jadual 8 memperlihatkan kesemua sub pemboleh ubah berada pada tahap purata yang tinggi. Dapatan ini menunjukkan bahawa tahap amalan rendah karbon pelajar berada pada tahap yang tinggi secara keseluruhannya dan memuaskan. Ini adalah selari dengan model awal tingkah laku pro alam Kollmuss dan Agyeman (2002) yang menyatakan bahawa tahap amalan adalah selari dengan tahap pengetahuan, sikap dan nilai. Malah kajian Hanifah, Yazid, Mohmadisa, dan Nasir (2016) turut membuktikan bahawa pengetahuan dan sikap kelestarian yang didedahkan dalam program yang berterusan serta terpimpin mampu membentuk amalan kelestarian yang positif pelajar sekolah.

Jadual 8 Tahap amalan rendah karbon

\begin{tabular}{lccccccccc}
\hline \multicolumn{1}{c}{ Pemboleh ubah } & \multicolumn{2}{c}{ Tahap Rendah } & \multicolumn{2}{c}{ Tahap Sederhana } & \multicolumn{2}{c}{ Tahap Tinggi } & Min & SP & $\begin{array}{c}\text { Tahap } \\
\text { purata }\end{array}$ \\
& $\mathbf{N}$ & $\boldsymbol{\%}$ & $\mathbf{N}$ & $\boldsymbol{\%}$ & $\mathbf{N}$ & $\boldsymbol{\%}$ & & & \\
\hline $\begin{array}{l}\text { Tahap Amalan Rendah } \\
\text { Karbon }\end{array}$ & 5 & 1.1 & 187 & 40.4 & 271 & 58.5 & 3.80 & 0.64 & Tinggi \\
- Penjimatan Tenaga & 13 & 2.8 & 184 & 39.7 & 266 & 57.5 & 3.67 & 0.58 & Tinggi \\
- Aktiviti Kitar Semula & 9 & 1.9 & 154 & 33.3 & 300 & 64.8 & 3.91 & 0.78 & Tinggi \\
- Mod Perjalanan & 27 & 5.8 & 163 & 35.2 & 273 & 59.0 & 3.81 & 0.92 & Tinggi \\
\hline
\end{tabular}

Secara keseluruhannya, dapatan kajian menunjukkan majoriti sub pemboleh ubah kajian berada pada tahap yang tinggi (Rajah 1). Ini menunjukkan bahawa tahap literasi pelajar adalah berada pada tahap yang membanggakan di Wilayah Persekutuan Putrajaya. Usaha yang dilaksanakan oleh pihak wilayah ini dalam membentuk bandar rendah karbon dilihat berjaya sedikit sebanyak mempengaruhi tahap literasi karbon pelajar di kawasan ini. 


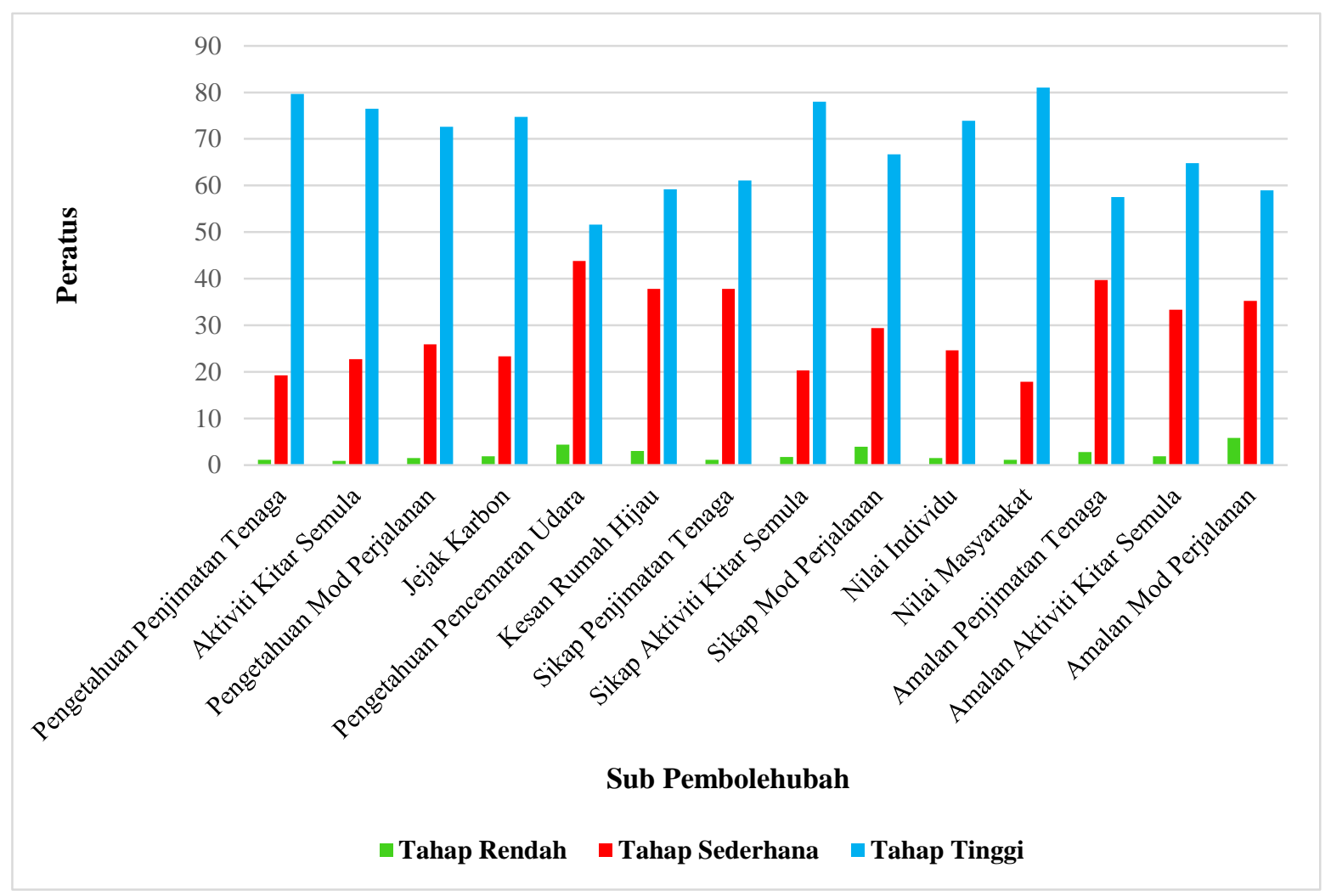

Rajah 1 Tahap keseluruhan sub pemboleh ubah kajian

\subsection{KESIMPULAN}

Kajian ini menunjukkan tahap pengetahuan jejak karbon, sikap rendah karbon, nilai celik karbon dan amalan rendah karbon berada pada tahap yang tinggi secara keseluruhannya kecuali sub pemboleh ubah pengetahuan pencemaran udara yang berada pada tahap sederhana. Ini menunjukkan secara dasarnya tahap literasi pelajar adalah berada pada tahap yang membanggakan di Wilayah Persekutuan Putrajaya. Keadaan ini jelas memberikan implikasi yang positif dengan sasaran bandar Wilayah Persekutuan Putrajaya sebagai Bandar Rendah Karbon dan Bandar Hijau 2025. Namun kajian ini dilihat tidak meliputi keseluruhan gambaran tahap literasi karbon pelajar di Malaysia. Untuk kajian akan datang, literasi karbon perlu dilihat sebagai bersifat amalan yang berterusan dan adalah lebih baik kajian ini dijalankan secara bersemuka dan membuat kajian ini dengan lebih terperinci dan tidak terhad kepada satu kawasan sahaja. Kajian juga boleh diperbaiki dengan memberi tumpuan kepada saiz sampel yang lebih besar yang melibatkan pelajar seluruh Malaysia.

\section{Rujukan}

Anna, E. M. (2014). Quantifying and Understanding Ecological Literacy: A Study Of First Year Students At Liberal Arts Institutions. Dickinson College. Ary, D., Jacob, L. C., \& Razaviech, A. (2002). Introduction To Research In Education. Belmont, California: Wadsworth.

Barrow, L. H., \& Morrisey, J. T. (1987). Ninth-grade students' attitudes toward energy: A comparison between Maine and New Brunswick. The Journal of Environmental Education, 18(1987), 15-21.

Bruyere, B. L. (2008). The Effect Of Environmental Education On The Ecological Literacy Of First-Year College Students. Journal of Natural Resources and Life Sciences Education, 37(2008), 20-26.

Cambridge Assessment. (2013). What is Literacy? An Investigation Into Definitions Of English As A Subject And The Relationship Between English, Literacy And "Being Literate." England.

Candice, S. (2013). Carbon Literacy Practices: Textual Footprints Between School And Home In Children's Construction Of Knowledge About Climate Change. Local Environment: The International Journal of Justice and Sustainability, 18(3), 289-304.

Chikaire, J. U., Ani, A. O., Nnadi, F. N., \& Godson-Ibeji, C. C. (2015). Energy Extension And Energy Literacy For Sustainable Energy Development In Rural Nigeria. Agricultural Advances, 4(8), 84-92.

DeWaters, J., \& Powers, S. (2012). Establishing Measurement Criteria For An Energy Literacy Questionnaire. Journal of Environmental Education, 44(1), 56-78.

Gioconda, M. M., Denisse, A. M., \& Alfredo, M. L. (2016). Case Reports in Pediatrics, 2016(8760504), 3.

Hanifah, M. (2014). Kesedaran dan Komitmen Pendidikan Pembangunan Lestari Dalam Komuniti Sekolah Menerusi Program Sekolah Lestari di Malaysia. Universiti Pendidikan Sultan Idris.

Hanifah, M., Shaharudin, I., Mohmadisa, H., Nasir, N., \& Yazid, S. (2015). Transforming Sustainability Development Education in Malaysian Schools through Greening Activities. Review of International Geographical Education Online ORIGEO, 5(1), 78-94.

Hanifah, M., Yazid, S., Mohmadisa, H., \& Nasir, N. (2016). Model Development on Awareness of Education for Sustainable Schools Development in Malaysia. Indonesian Journal of Geography, 48(1), 39-48.

Hussain, T. P. R. S., Ismail, H., \& Noh, M. K. M. (2013). Kesedaran Mengenai Penjimatan Tenaga Elektrik dan Kelestarian Alam Sekitar. PROSIDING PERKEM VIII, 2, 977-990. 
Intergovernmental Panel on Climate Change (IPCC). (2014). Climate Change 2014: Synthesis Report. Contribution of Working Groups I, II and III to the Fifth Assessment Report of the Intergovernmental Panel on Climate Change. (R. K. Pachauri \& L. A. Meyer, Eds.). Geneva, Switzerland: IPCC.

Joseph, C., Nichol, E., Janggu, T., \& Madi, N. (2013). No Title. International Journal of Sustainability in Higher Education, 14(2), 196-208.

KeTTHA. (2015). Laporan Tahunan 2014. Putrajaya.

Kollmuss, A., \& Agyeman, J. (2002). Mind The Gap: Why Do People Act Environmentally And What Are The Barriers. Carfax Publishing, Taylor \& Francis Group

Lance, C. E., Butts, M. M., \& Michels, L. C. (2006). The Sources Of Four Commonly Reported Cutoff Criteria: What Did They Really Say? Organizational Research Methods, 9(2), 202-220.

Launiala, A. (2009). How Much Can A KAP Survey Tell Us About People's Knowledge, Attitudes And Practices? Some Observations From Medical Anthropology Research On Malaria In Pregnancy In Malawi. Anthropology Matters Journal, 11(1), 1-13.

Manchester Carbon Literacy Project. (2012). Carbon Literacy: The Manchester Carbon Literacy Standard.

Maryland Association for Environmental \& Outdoor Education (MAEOE). (2016). Environmental Literacy. Maryland.

Milena, B., Graham, S., \& Rebecca, E. (2011). Low-Carbon Practices: A Third Sector Research Agenda.

Muhammad Rizal, R., \& Jamaluddin, M. J. (2010). Kelestarian Dalam Perjanjian Alam Sekitar Pelbagai hala: Sudut pandangan Malaysia. Malaysian Journal of Environmental Management, 11(2), 33-43.

Nor Juliana, A. A., Mohd Yazid, M. Y., Nor Atiah, I., \& Md Azree, O. M. (2015). Developing low-Carbon Awareness And Low-Carbon Behaviour Framework For Tackling CO2 Emission In A City. Applied Mechanics and Materials, 747(2015), 265-268.

Norzalika, M. Z. (2011). Tahap Pengetahuan, Sikap Dan Amalan Terhadap Penggunaan Lestari Dalam Kalangan Pelajar Sekolah Menengah Di Bandar. Universiti Putra Malaysia.

Orr, D. (1992). Ecological Literacy. New York: SUNY Press.

Persatuan Penyelidikan Air dan Tenaga Malaysia, (AWER). (2012). Menghentikan Penggunaan Mentol Berfilamen : Adakah Malaysia Melakukannya Dengan Betul?

Puteri Musfirah, M. J. (2011). Tahap Pengetahuan, Sikap Dan Amalan Penggunaan Lestari Dalam Kalangan Pelajar Sekolah Menengah Di Bandar. Universiti Putra Malaysia.

Riebeek, H. (2007). Global Warming. National Aeronautics and Space Administration (NASA): Earth Observatory. Diambil daripada http://earthobservatory.nasa.gov/Features/GlobalWarming/global_warming_2007.pdf.

Rosnani, I. (2011). FORESTS : Nature at Your Service. Era Hijau.

Salwati, Y. (2013). Pembinaan dan Pengesahan Instrumen Literasi Alam Sekitar Pelajar Sekolah Menengah. Universiti Sains Malaysia.

Schwartz, N. E. (1976). Nutrition Knowledge, Attitudes And Practices Of Canadian Public Health Nurses. Journal of Nutrition Education, 8(2), $28-31$.

Shahrom, M. Z., Wan Hamidon, W. B., Rahmah, El., Noor Ezlin, A. B., Nuraini, K. S., \& Azami, Z. F. (2009). Kaji Selidik Pendidikan Alam Sekitar Dan Keperluan Kepada Pembangunan Lestari Dalam Proses Pengajaran Dan Pembelajaran. Seminar Pendidikan Kejuruteraan dan Alam Bina. Bangi: Universiti Kebangsaan Malaysia.

Tiwi, K. (2006). Perkaitan Antara Pengetahuan Dan Sikap Terhadap Alam Sekitar Di Kalangan Guru Pelatih Maktab Perguruan Batu Lintang. Jurnal Penyelidikan IPBL, 7(2006), 61-77.

UNESCO. (2006). Education For All Global Monitoring Report 2006: Understandings Of Literacy.

Unit Perancang Ekonomi, J. P. M. (2015). Rancangan Malaysia Kesebelas 2016-2020. Putrajaya.

United States Global Change Research Program (2009). Climate literacy: The Essential Principles Of Climate Sciences. Washington DC: United States Global Change Research Program. Diambil daripada http://oceanservice.noaa.gov/education/literacy/climate_literacy.pdf

World Health Organization. (2016). Climate Change And Human Health - Risks And Responses. 